\title{
I Have Loved Me a Man: The Life and Times of Mika
}

By Sharon Mazer. Auckland University Press, Auckland, 2018.

RRP: \$59.99 ISBN 9781869408862

Reviewed by Kareem Khubchandani

How to be queer, brown, and fabulous in the wake of colonial violence? Queer indigenous scholars help us understand that imperialist Euro-Western forms of knowledge insinuate themselves globally through the medical industrial complex, religion, media, law, and other forms of governance, as well as through physical and sexual violence. In these circumstances, indigenous gender and sexual matrices are reduced to simplistic binaries. Gender and sexual forms such as bakla, two-spirit, fa'afafine, or takatäpui become less available to us under ongoing processes of colonial modernity, less legible in the public sphere. These identities are attached to expressive practices that enable fabulation: storytelling, creation, and making that can engender other worlds-losing them means losing particular kinds of fabulosity. I Have Loved Me a Man: The Life \& Times of Mika is an important meditation on the possibilities and challenges of fabulating ways out of a colonial gender matrix through performance. Sharon Mazer's book, written in accessible and engaging prose, moving nimbly from biography to history to critical theory, charts the life of virtuosic gay Māori performer Mika. As a theatre and performance scholar, Mazer astutely captures how performance works as a tool for the negotiation of socio-political hierarchies manufactured in the wake of colonization, while also considering the political economy of performance industries, the limits they place on the mobility and success of minoritarian artists.

New Zealand-based and globally circulating Māori artist Mika was born Neil Gudsell in 1962, and raised by an adoptive white family. Because indigenous performance and ways of knowing were not available to Mika growing up except through pop-culture representations on Weet-Bix cereal boxes and elsewhere, Mika's life and artistry are an exploration in embodying race in messy ways that set indigeneity in motion, instead of fixing it in time. Race and performance mattered even before Mika's birth; both his birth parents were Māori, but his mother passed as white in order to live in Timaru. In line with under-documented processes of ethnic cleansing, Mika was forcibly taken from his birth-mother on the assumption that he was mixed race, and given to a white family. Early forays into performance came on the stage of everyday life, being brown at a predominantly white school and expressing his gayness through flamboyant dress. Mika was also an athlete, and as a disco-crazed teenager, he transitioned into teaching jazzercise and hip hop.

In Mika's tendency toward hip hop, disco, and jazz we see early affinities for black performance. Blackness was not merely spectral in the form of globally circulating popular dance; Mika had an African American lover whom he lost to AIDS; his turn to solo performance was inspired by Whoopi Goldberg and Grace Jones; and he developed work alongside the Pomo Afro Homos. Important conversations in indigenous studies critique critical race and diaspora analytics for their interest in mobility and travel that elide indigenous attachments to land. But Mika's story helps us understand how black diasporic performance came to New Zealand as popular culture and enabled him to articulate racial difference. Moreover, as an indigenous performance artist he had to travel globally in order garner legitimacy for his art in order to sustain a living locally, to be "world famous, and not just in New Zealand" (166). 
Mika complemented his diasporic arts acquired in collaborations with African American artists, Indo-Japanese performer Shakti, and even Grace Jones herself, with distinctly Māori aesthetics. His indigenous influences were not just cobbled together popular representations of Māori people, but also immersive collaborations with other Aotearoa artists. His work is indebted to mentorship from filmmaker Maramena Roderick, transgender drag queen and activist Carmen Rupe, filmmaker Merata Mita who directed his show Uncooked, and arts and community activist Dalvanius Prime who was the producer for his single "I Have Loved me a Man." Mika's indigenous aesthetics also drew from syncretized music such as kapa haka, as well as collaborations with Māori theatre company Te Ohu Whakaari. He innovated indigeneity, kept it in motion, by playing with language, song, costume, and body paint. In some instances these were homoerotically charged haka remixed with pop songs, and in others they are highly sexualized burlesques of indigenous tropes that required audiences to interrogate their own desire for exoticized brown bodies.

Through burlesque, camp, drag, rock concert, and studio and street dance, Mika used his body to make and unmake gender. Mazer's arguments about Mika's critical deployment of gender as performance is fortified by her extensive inclusion of photographs of Mika on and off stage. The reader bears witness to Mika's mastery over pose, his ability to create angles and curves across his body so that we see him differently every time. He uses dress and makeup that put masculinity, androgyny, femininity, high fashion, indigenous dress, and sports/dancewear into tension with each other. Discourses about gender crossing and drag are deeply invested in the sartorial, but Mika's command over pose rendered in fully nude images remind us of how people do gender without relying on material resources extraneous to the body. His virtuosic ability to make new shapes in his body conjures a brown queerness that diverts interpretation away from simple masculine-feminine binaries.

Mika's gayness is central to the biography, from childhood through his global circulation, and his sex-positive approach to art-making brings him into conflict with other artists and activists. In his school days, Mika wore heels and catsuits and kissed boys; unexpectedly, being both gay and Māori gave Mika an edge, it "made him appear exotic and charismatic instead of (or possibly as well as) deviant and dangerous" (22). In his 1990 remake of Allison Durbin's 1968 track "I Have Loved Me a Man," Mika repurposes the heteronormative lyrics to sing about gayness, including in music video safer-sex text and queer imagery of muscular male bodies and drag queens. His turn to explicit sexuality in video and performance upset both homophobic conservatives and queer folks who worried about sexualized representations of brown bodies amidst mainstream panics during the AIDS crisis. While filming his infamous role as Tahu, a takatātapui character in The Piano (Dir. Jane Campion, 1993), Mika came into conflict with other Māori actors who viewed his gayness as inauthentic to being Māori.

Mazer's study of Mika's life as a performer testifies to the precarity of art as a form of work, especially for minoritarian artists and for avant garde styles that do not neatly fit institutionalized aesthetic frameworks. That it is Mika's story being told in such detail is because he luckily survived an epidemic that many other queer people did not, and throughout the book readers are reminded of the many friends and lovers Mika lost to AIDS across his life and career. But even Mika's global mobility, TV appearances, celebrity collaborations, and local popularity do not

Journal of New Zealand Studies NS28 (2019), 137-139 https://doi.org/10.26686/jnzs.v0iNS28.5429 
amount to stability. Throughout, we regularly find Mika, after a new venture or tour, broke. Producers reneged on their contracts, disappeared, or stopped paying. Unexpected sources such as the Winston Churchill Memorial Trust funded Mika's global travel to study AIDS education theatre programs; in addition to being a dancer, TV actor, singer, cabaret artist, nightlife promoter, and fitness instructor, Mika had to be creative as a fundraiser too. It is for this reason that he launches Torotoro, a company committed to supporting young Māori artists who could perform with him, and to whom he could offer resources about healthy living and navigating institutional art spaces.

In the interdisciplinary field of theatre and performance studies, our scholarship can be strangely disciplinary, focusing on specific genres, media, methods, or time periods. It is thus exceptionally refreshing to read about some fifty years of Mika's life as he indulges in dance, protest, theatre, avant garde art making, cabaret, music, studio-based instruction, sports, street dance, disco, and nightlife. Sharon Mazer takes each of these styles seriously as performance. In doing so she renders I Have Loved Me a Man an expansive embodiment of performance studies' axioms: everything is performance, and performance is a useful way of seeing the world. Complementing Mika's variegated career is Mazer's dynamic research method. She accompanies oral histories with Mika and his contemporaries with an extensive archive of other interviews they have given. She reads photographs of Mika in his youth closely, and astutely analyzes film documentation of live performances. She brings camp to visual analysis, finding ways that Mika winks at his gay audience before he identified as gay, or when playing straight roles on TV. Literary analysis is also useful to Mazer as she probes how critics read Mika's shows, and discusses a character that Mika inspired in Witi Ihimaera's novel Nights in the Gardens of Spain. These original readings are paired with short forays into critical indigenous studies, deconstructionist approaches to gender, political economic histories of New Zealand, and queer performance theory written in prose accessible to popular readers and cultural studies scholars alike.

Reading a British critic's interview with Mika, Mazer is especially disappointed by author's dismissive voice and says, "Who needs to perform the cultural cringe when such journalists can do it for you, one wonders" (138). In this quote, Mazer is protective of Mika; though we do not get to witness their relationship develop through a more ethnographic mode of writing, her fondness for Mika is clear. Mazer's book expresses awe for Mika's innovative and evolving body of work from childhood onward, his ability to survive a precarious art market as a queer indigenous artist, his capacity to return to work after conflicts and losses, his commitment to furthering Māori performance through mentorship, and his perseverance as an adopted gay Māori constantly navigating environments that can't fully grasp his fabulousness. 